\title{
Fast and Interference Free Determination of Calcium and Magnesium in Honeys by Solid Phase Extraction Followed by Flame Atomic Absorption Spectrometry
}

\author{
Pawel Pohl,* Helena Stecka and Piotr Jamroz \\ Department of Analytical Chemistry, Faculty of Chemistry, Wroclaw University of Technology, \\ Wybrzeze Stanislawa Wyspianskiego 27, 50-372 Wroclaw, Poland
}

\begin{abstract}
Um procedimento para preparo de amostras, baseado na extração em fase sólida e eluição em duas etapas foi desenvolvido para a determinação da concentração total de $\mathrm{Ca}$ e $\mathrm{Mg}$ em méis de abelha. As amostras de mel foram tratadas como segue: soluções de amostra $(50 \mathrm{~mL})$ a $5,0 \%(\mathrm{~m} / \mathrm{v})$ foram passados a uma vazão de $20 \mathrm{~mL} \mathrm{~min}^{-1}$, através de resina Dowex $50 \mathrm{~W} \times 8-400$, para reter íons $\mathrm{Ca}$ (II) e $\mathrm{Mg}$ (II) e separá-los da matriz contendo glicose e frutose, e dos minerais aniônicos. Depois, $20 \mathrm{~mL}$ de uma solução de $\mathrm{HNO}_{3} 0,5 \mathrm{~mol} \mathrm{~L}^{-1}$ foram usados para remover os íons $\mathrm{K}$ e $\mathrm{Na}$. Finalmente, Ca e Mg foram eluídos com $5 \mathrm{~mL}$ de solução de $\mathrm{HCl}$ 2,0 $\mathrm{mol} \mathrm{L}^{-1}$ antes da medida de suas concentrações por espectrometria de absorção atômica em chama (FAAS). O procedimento proposto para o preparo da amostra foi rápido (30 min) e permitiu medir as concentrações de Ca e $\mathrm{Mg}$ em mel, com precisão de 1-5\% e exatidão de $1-3 \%$. Os limites de detecção de $24 \mathrm{ng} \mathrm{g}^{-1}$ de $\mathrm{Ca}$ e 4,4 $\mathrm{ng} \mathrm{g}^{-1}$ de $\mathrm{Mg}$ foram obtidos para FAAS com este procedimento.
\end{abstract}

A sample preparation procedure based on the solid phase extraction and the two-step elution was developed for the determination of the total concentrations of $\mathrm{Ca}$ and $\mathrm{Mg}$ in bee honeys. The honey samples were treated as follows: the $5.0 \%(\mathrm{~m} / \mathrm{v})$ sample solutions $(50 \mathrm{~mL})$ were passed at the flow rate of $20 \mathrm{~mL} \mathrm{~min}^{-1}$ through the resin beds of Dowex $50 \mathrm{~W} \times 8-400$ to retain the $\mathrm{Ca}$ (II) and $\mathrm{Mg}(\mathrm{II})$ ions and separate them from the matrix of glucose and fructose in addition to the anionic minerals. Afterwards, $20 \mathrm{~mL}$ of a $0.5 \mathrm{~mol} \mathrm{~L}^{-1} \mathrm{HNO}_{3}$ solution was used to remove the $\mathrm{K}$ and $\mathrm{Na}$ ions. Finally, $\mathrm{Ca}$ and $\mathrm{Mg}$ were eluted prior to the measurements of their concentrations by flame atomic absorption spectrometry (FAAS) using $5 \mathrm{~mL}$ of a $2.0 \mathrm{~mol} \mathrm{~L}^{-1} \mathrm{HCl}$ solution. The proposed sample preparation procedure was fast $(30 \mathrm{~min})$ and enabled to measure the concentrations of $\mathrm{Ca}$ and $\mathrm{Mg}$ in honey with the precision of $1-5 \%$ and the accuracy of 1-3\%. The limits of detection of $24 \mathrm{ng} \mathrm{g}^{-1}$ of $\mathrm{Ca}$ and $4.4 \mathrm{ng} \mathrm{g}^{-1}$ of $\mathrm{Mg}$ were obtained for FAAS with this procedure.

Keywords: $\mathrm{Ca}, \mathrm{Mg}$, honey, FAAS, solid phase extraction, ion exchange, sequential elution

\section{Introduction}

Calcium and magnesium, within the typical concentration range of $1-200 \mu \mathrm{g} \mathrm{g}^{-1}$, are nutritionally important minor elements of honey. ${ }^{1-5}$ Both elements are quite often determined in this matrix using air-acetylene flame atomic absorption spectrometry (FAAS), however, due to the complexity of the samples, i.e., the very high content of the monosaccharides, the easily ionized elements like $\mathrm{K}$ and $\mathrm{Na}$, phosphates and the other anions, their measurements with the aid of FAAS may encounter some problems related to the matrix effects. ${ }^{6}$ In reference to the possibility of the routine analyses and the quality and food safety control measurements of honey, the selection of a

*e-mail: pawel.pohl@pwr.wroc.pl suitable procedure for the sample treatment is of a special importance in this case because it decides about the time of the analysis and the dependability of the results.

The possible chemical and physical interferences linked to the presence of the aforementioned main organic and inorganic components of honey may be eliminated when the analyzed samples are decomposed using the different mineralization procedures, namely the dry ashing and the wet digestion with the oxidative reagents, while the concentrations of $\mathrm{Ca}$ and $\mathrm{Mg}$ are measured later on by FAAS in the resulting solutions of digests. ${ }^{1,2,4,5,7-13}$ Although both pointed sample preparation strategies, i.e., the calcination in the air and the wet decomposition, enable to extract the determined elements from the matrix of honey into the solutions and prevent the physical interferences related to the changes in the nebulization rate of the sample 
solutions, they are simply time-consuming and laborious. The subsequent stages of these procedures can additionally be responsible for losses (by the sample overheating and sputtering) or gains (by the contamination from the reagents and the vessels) of the elements. ${ }^{6}$

The direct analysis of honey on the content of $\mathrm{Ca}$ and $\mathrm{Mg}$, predated by the dilution of the respective samples in water or diluted solutions of the oxidizing reagents $\left(\mathrm{HNO}_{3}\right.$ mostly, $\mathrm{H}_{2} \mathrm{O}_{2}$ ) and the aspiration of the resulting solutions into FAAS, is less frequent due to profound matrix effects originating from the presence of fructose and glucose in addition to the mineral elements like $\mathrm{P}$ or $\mathrm{S}$. Although this method seems to be straightforward, a series of dilutions has to be done for each honey in order to assure that the selected content of honey in the analyzed solutions and the constituents that could potentially interfere with the $\mathrm{Ca}$ and $\mathrm{Mg}$ measurements would not affect the analytical response for these elements in FAAS. ${ }^{3,4,14-16}$ What is more, although the $2-5 \%(\mathrm{~m} / \mathrm{v})$ honey solutions can directly be measured by FAAS, the load of the organic matter and the main mineral constituents in the solutions of such untreated samples may still be high. So that, the flow injection manifolds have to be used to decrease it $\mathrm{it}^{3,15}$ or the analyzed sample solutions are further diluted. ${ }^{4}$

Irrespective of that if the solutions of the digested or the undigested samples of honey are analyzed, serious non-spectral interferences in the flame can be observed due to the enhanced ionization of $\mathrm{Ca}$ and $\mathrm{Mg}$ in the nitrous oxide-acetylene flames or the occlusion of these elements into the refractory or the less volatile molecules produced in the reactions with the phosphates in the air-acetylene flames. As a result, the releasing buffers like $\mathrm{NaCl}$ or $\mathrm{KCl}^{1,5}$ and/or La containing compounds like $\mathrm{La}_{2} \mathrm{O}_{3}, \mathrm{La}\left(\mathrm{NO}_{3}\right)_{3}$ or $\mathrm{LaCl}_{3}{ }^{1-5}$ are commonly added to the analyzed sample and standard solutions. This preparation step certainly increases the time of the analysis and the included labor investment. With respect to the described problems of the prolonged analysis of honey when the samples are digested by the dry or wet ashing procedures and subsequently diluted or mixed with the solutions of the aiding substances, the development of the alternative approaches that enable the fast and the interference free analysis of honey by FAAS would seem to be valuable in terms of the simplification of the whole analytical procedure.

The objective of this work was to develop a solid phase extraction (SPE) procedure for the preparation of honey prior to the determinations of $\mathrm{Ca}$ and $\mathrm{Mg}$ using the common air-acetylene FAAS. Initially, the sorption behavior of the commercially available strongly acidic cation exchangers, including Amberlite IRP-69, Dowex 50W×8-200, Dowex $50 \mathrm{~W} \times 8-400$ and Dowex HCR-W2, toward the $\mathrm{Ca}(\mathrm{II}), \mathrm{K}$,
$\mathrm{Mg}(\mathrm{II})$ and $\mathrm{Na}$ ions as well as fructose and glucose was studied in the conditions of the different solution $\mathrm{pH}$ and the flow rates across the SPE columns. For the selected Dowex 50W $\times 8-400$ resin, the conditions of the two-step elution aimed at the removal of the $\mathrm{K}$ and $\mathrm{Na}$ ions in the first step and the recovery of the $\mathrm{Ca}$ (II) and $\mathrm{Mg}$ (II) ions in the second step before the determination of their concentrations by FAAS were established. The reliability of a devised SPE sample preparation procedure was verified by the comparison of its results with those obtained with the other sample preparation procedures. The spiking experiments were conducted as well and the respective recoveries were assessed. The procedure was applied for the determination of the concentrations of $\mathrm{Ca}$ and $\mathrm{Mg}$ in six raw mono- and multi-flower honeys.

\section{Experimental}

\section{Reagents and materials}

Ultra-pure water from a WIGO (Wroclaw, Poland) PRO-11G reverse osmosis water purification system was used throughout. The ACS grade concentrated reagents, i.e., $30 \%(\mathrm{~m} / \mathrm{m}) \mathrm{H}_{2} \mathrm{O}_{2}, 37 \%(\mathrm{~m} / \mathrm{m}) \mathrm{HCl}, 65 \%(\mathrm{~m} / \mathrm{m})$ $\mathrm{HNO}_{3}$ and $96 \%(\mathrm{~m} / \mathrm{m}) \mathrm{H}_{2} \mathrm{SO}_{4}$ solutions, were purchased from J. T. Baker (Deventer, Netherlands). D-fructose (purity $>98 \%$ ) and D-glucose (purity $>98 \%$ ) were supplied by POCH (Gliwice, Poland). The other solid reagents were also taken from $\mathrm{POCH}$ and were used for the preparation of alkaline $6.0 \mathrm{~g} \mathrm{~L}^{-1} \mathrm{CuSO}_{4}, 50 \mathrm{~g} \mathrm{~L}^{-1}\left(\mathrm{NH}_{4}\right)_{6} \mathrm{Mo}_{7} \mathrm{O}_{24}$, $6.0 \mathrm{~g} \mathrm{~L}^{-1} \mathrm{Na}_{2} \mathrm{HAsO}_{4}, 0.5(\mathrm{~m} / \mathrm{v}) \mathrm{LaCl}_{3}$ and $0.5 \%(\mathrm{~m} / \mathrm{v}) \mathrm{CsCl}$ solutions. A solution of the arseno-molybdate reagent was prepared by reaction of the $\left(\mathrm{NH}_{4}\right)_{6} \mathrm{Mo}_{7} \mathrm{O}_{24}$ and $\mathrm{Na}_{2} \mathrm{HAsO}_{4}$ solutions in the medium of a $0.8 \mathrm{~mol} \mathrm{~L}^{-1} \mathrm{H}_{2} \mathrm{SO}_{4}$ solution. The Titrisol single-element AAS standards from Merck KGaA (Darmstadt, Germany) were applied to prepare $1000 \mathrm{mg} \mathrm{mL}^{-1}$ single-element stock standard solutions of $\mathrm{Ca}, \mathrm{K}, \mathrm{Mg}$ and $\mathrm{Na}$. These solutions were used to prepare the standard solutions of $\mathrm{Ca}, \mathrm{K}, \mathrm{Mg}$ and $\mathrm{Na}$ for the calibration as well as the $50 \mathrm{~mL}$ working standard solutions containing 2.0, 50, 0.5 and $2.0 \mathrm{mg} \mathrm{mL}^{-1}$ of $\mathrm{Ca}, \mathrm{K}, \mathrm{Mg}$ and $\mathrm{Na}$, respectively, in addition to $20 \mathrm{mg} \mathrm{mL}^{-1}$ of fructose and glucose. This composition represented an average content of the studied constituents in the $5.0 \%(\mathrm{~m} / \mathrm{v})$ water solutions of Polish honeys. ${ }^{17,18}$ The latter solutions were acidified with a $0.01 \mathrm{~mol} \mathrm{~L}^{-1} \mathrm{HCl}$ solution to reach the $\mathrm{pH}$ of 3.5, 4.0 and 4.5 and then used in the study of the cation exchange behavior of $\mathrm{Ca}, \mathrm{K}, \mathrm{Mg}, \mathrm{Na}$, fructose and glucose toward the resins applied.

The strong cation exchange styrene-divinylbenzene resins with the sulphonic acid functional groups, i.e., 
Amberlite IRP-69 (100-500 mesh size, $\mathrm{Na}^{+}$form), Dowex 50W $\times 8-200$ (100-200 mesh size, $\mathrm{H}^{+}$form), Dowex 50W $\times 8-400\left(200-400\right.$ mesh size, $\mathrm{H}^{+}$form) and Dowex HCR-W2 (16-40 mesh size, $\mathrm{H}^{+}$form), were supplied by Sigma-Aldrich (Saint Louis, MO, USA). The SPE columns $(1.0 \mathrm{~cm}$ of the inner diameter $)$ from Sigma-Aldrich were equipped with the glass coarse frits and the polytetrafluoroethylene (PTFE) stopcocks. They were filled with the water slurries of the cation exchange resins (the $1.0 \mathrm{~g}$ portions) and then, the resin beds formed were washed with $10 \mathrm{~mL}$ of a $2.0 \mathrm{~mol} \mathrm{~L}{ }^{-1} \mathrm{HCl}$ solution at the flow rate of $5.0 \mathrm{~mL} \mathrm{~min}{ }^{-1}$. Afterward, the resin beds were rinsed with $50 \mathrm{~mL}$ of water to remove the excess of $\mathrm{HCl}$.

The Cole-Parmer (Vernon Hill, IL, USA) 4-channel MasterFlex L/S peristaltic pumps were used to control and measure the flow rates of the solutions that were passed through the columns.

\section{Instrumentation}

A Perkin Elmer single-beam air-acetylene flame atomic absorption spectrometer model 1100B with standard accessories, i.e., a wettable plastic coated burner mixing chamber, a drain interlock assembly, a $10 \mathrm{~cm}$ long $\mathrm{Ti}$ single slot burner head and a stainless steel nebulizer, was used in the measurements. The determinations of the $\mathrm{Ca}$ and $\mathrm{Mg}$ concentrations were carried out in an absorption mode (FAAS) while the concentrations of $\mathrm{K}$ and $\mathrm{Na}$ were determined using the same instrument but operated in an emission mode (flame optical emission spectrometry, FOES). The absorbance and the emission intensities were recorded using a time-average integration mode. In each read cycle, 3 readings integrated at $0.1 \mathrm{~s}$ intervals over a $1 \mathrm{~s}$ integration time were taken. The spectrometer was operated under the standard working parameters given in Table 1.

A Thermo Scientific (Bremen, Germany) single-beam visible spectrophotometer model Spectronic $20 \mathrm{D}^{+}$was used to measure the sum of fructose and glucose with the aid of the Somogyi-Nelson (arseno-molibdate) method. ${ }^{19}$
In brief, $500 \mu \mathrm{L}$ of an alkaline $\mathrm{CuSO}_{4}$ solution were added to the $10 \mu \mathrm{L}$ sample portions. The resulting mixtures were incubated in a water bath at the temperature of $90{ }^{\circ} \mathrm{C}$ for 10 min to reduce the ions of $\mathrm{Cu}(\mathrm{II})$ to $\mathrm{Cu}(\mathrm{I})$. After cooling, a solution of the arseno-molybdate reagent was added to react with the $\mathrm{Cu}(\mathrm{I})$ ions and produce a polymolybdate complex (molybdenum blue) of the intensive blue color. The absorbance readings of the final solutions containing the molybdenum blue were taken at $520 \mathrm{~nm}$. The sums of the concentrations of fructose and glucose were determined against the standard solutions of glucose being within the concentration range of $1.0-50 \mathrm{mg} \mathrm{mL}^{-1}$.

\section{Preparation of honey and analysis by FAAS}

The samples of freshly ripened honeys, including acacia, goldenrod, heather, lime, multi-floral, lime and rape, were from an apiary placed in the suburbs of Wroclaw (Lower Silesian Province, Poland). Honeys were kept in the original glass jars used for their shipping.

Four different means of the sample treatment were used to prepare the sample solutions before the measurements of the concentrations of $\mathrm{Ca}$ and $\mathrm{Mg}$ in the analyzed honeys by FAAS. In case of the wet oxidative digestion in the mixture of the concentrated $\mathrm{HNO}_{3}$ and $30 \%(\mathrm{~m} / \mathrm{m}) \mathrm{H}_{2} \mathrm{O}_{2}$ solutions (the procedure $\mathrm{A}$ ), the $2.5 \mathrm{~g}$ samples of the analyzed honeys were placed in the $250 \mathrm{~mL}$ beakers, dissolved in $10 \mathrm{~mL}$ of water, poured with $10 \mathrm{~mL}$ of $\mathrm{HNO}_{3}$ and heated under the cover at the temperature of $85-90{ }^{\circ} \mathrm{C}$ for about $2.5 \mathrm{~h}$. Afterward, $10 \mathrm{~mL}$ of $\mathrm{H}_{2} \mathrm{O}_{2}$ were added to the solutions and the heating was extended for next $1 \mathrm{~h}$ to decompose the oxidant and reduce the volume of the sample solutions to about 1-2 mL. The resulting aliquots were re-constituted with water to $50 \mathrm{~mL}$. In a similar way, the samples of the analyzed honeys were digested using two $10-\mathrm{mL}$ portions of a $30 \%(\mathrm{~m} / \mathrm{v}) \mathrm{H}_{2} \mathrm{O}_{2}$ solution only (the procedure $\left.\mathrm{B}\right)$. In case of the water dissolution (the procedure $\mathrm{C}$ ), the $2.5 \mathrm{~g}$ samples of the analyzed honeys were placed in the $250 \mathrm{~mL}$ beakers, dissolved in about $10 \mathrm{~mL}$ of water and finally diluted with it

Table 1. The operating conditions for the measurements of $\mathrm{Ca}$ and $\mathrm{Mg}$ (by FAAS) and $\mathrm{K}$ and $\mathrm{Na}$ (by FOES)

\begin{tabular}{|c|c|c|c|c|}
\hline & $\mathrm{Ca}$ & K & $\mathrm{Mg}$ & $\mathrm{Na}$ \\
\hline Air flow rate / $\left(\mathrm{L} \mathrm{min}{ }^{-1}\right)$ & 8.0 & 8.0 & 8.0 & 8.0 \\
\hline $\mathrm{C}_{2} \mathrm{H}_{2}$ flow rate $/\left(\mathrm{L} \mathrm{min}^{-1}\right)$ & 1.2 & 1.2 & 1.2 & 1.2 \\
\hline Lamp current / mA & 10 & 7 & 6 & 10 \\
\hline Wavelength / nm & 422.7 & 766.5 & 285.2 & 589.0 \\
\hline Slit / nm & 0.7 & 0.4 & 0.7 & 0.2 \\
\hline Upper calibration range / $\left(\mathrm{mg} \mathrm{mL}^{-1}\right)$ & 10.0 & 1.0 & 2.0 & 1.0 \\
\hline Instrumental limit of detection ${ }^{\mathrm{a}} /\left(\mathrm{ng} \mathrm{mL}^{-1}\right)$ & 18 & 0.4 & 2.5 & 1.1 \\
\hline
\end{tabular}

a $3 \times \mathrm{SD}$ of the mean signals for a water blank $(n=5)$. 
to $50 \mathrm{~mL}$. The sample solutions achieved after the execution of the procedures $\mathrm{A}, \mathrm{B}$ and $\mathrm{C}$ were diluted 2 times with $0.5 \%$ $(\mathrm{m} / \mathrm{v}) \mathrm{LaCl}_{3}$ and $0.5 \%(\mathrm{~m} / \mathrm{v}) \mathrm{CsCl}$ solutions and measured by FAAS against the standard solutions containing the same amounts of both chloride salts.

In case of the SPE procedure (the procedure D), the $2.5 \mathrm{~g}$ samples of the analyzed honeys were placed in the $250 \mathrm{~mL}$ beakers, dissolved in $10 \mathrm{~mL}$ of water and diluted with it to $50 \mathrm{~mL}$. The resulting sample solutions were passed through the SPE columns of Dowex 50W $\times 8-400$ at the flow rate of $20 \mathrm{~mL} \mathrm{~min}^{-1}$ to retain $\mathrm{Ca}$ and $\mathrm{Mg}$ and separate these elements from the main monosaccharides and the anionic minerals (mostly phosphates). Next, $20 \mathrm{~mL}$ of a $0.5 \mathrm{~mol} \mathrm{~L}^{-1} \mathrm{HNO}_{3}$ solution was passed through them

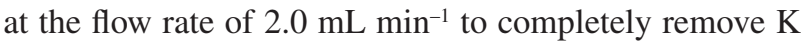
and Na. Finally, $5 \mathrm{~mL}$ of a $2.0 \mathrm{~mol} \mathrm{~L}^{-1} \mathrm{HCl}$ solution at

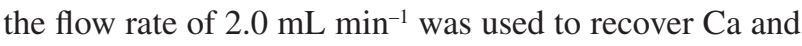
$\mathrm{Mg}$ from the SPE columns. The respective eluates were diluted with water to $25 \mathrm{~mL}$ with water and subjected to the measurements by FAAS versus the simple standard solutions.

\section{Results and Discussion}

All the retention, the separation and the elution efficiencies were mean values for six independent replicates. The respective column blanks were run at each step and considered in the final results. Three independent analyses of honey samples were made using different sample preparation procedures. The respective procedural blanks were prepared, analyzed and considered in the final results of the analysis.

\section{Cation exchange behavior of element ions and monosaccharides}

The cation exchange behavior of the studied resins toward the $\mathrm{Ca}$ (II), $\mathrm{K}, \mathrm{Mg}$ (II) and $\mathrm{Na}$ ions and fructose and glucose was investigated by passing the $50 \mathrm{~mL}$ working standard solutions ( $\mathrm{pH} 3.5,4.0$ and 4.5) through the SPE columns at the flow rate of $2.0 \mathrm{~mL} \mathrm{~min}^{-1}$ and analyzing the respective column effluents (each time, the $10 \mathrm{~mL}$ portions were collected by the end of the solution loading). The concentrations of the elements in these effluents were determined by FAAS ( $\mathrm{Ca}, \mathrm{Mg}$ ) and FOES (K, Na) versus the calibration with the matrix matching standard solutions (with fructose and glucose at the concentration of $20 \mathrm{mg} \mathrm{mL}^{-1}$ of each). The concentrations of the sum of fructose and glucose were measured using the Smogoyi-Nelson method. ${ }^{19}$ The retention efficiencies of $\mathrm{Ca}, \mathrm{K}, \mathrm{Mg}$ and $\mathrm{Na}$ (in \%) and the separation efficiencies of fructose and glucose (in \%) were calculated considering the concentrations of these constituents found in the column effluents and their initial concentrations in the working standard solutions.

In this experiment it was found that all the cation exchange resins, i.e., Amberlite IRP-69, Dowex 50W×8-200, Dowex $50 \mathrm{~W} \times 8-400$ and Dowex 50W HCR-W2, completely retain the $\mathrm{Ca}$ (II) and $\mathrm{Mg}$ (II) ions and separate them from fructose and glucose irrespectively of the studied solution $\mathrm{pH}$. The latter monosaccharides passed in these conditions through the resin beds unretained. Accordingly, the retention efficiencies established for both elements were within 99.2-100.0\% (Amberlite IRP-69), 99.6-99.9\% (Dowex $50 \mathrm{~W} \times 8-200), 99.8-100.0 \%$ (Dowex $50 \mathrm{~W} \times 8-400)$ and 99.0-99.8\% (Dowex 50W HCR-W2) with the coefficients of variance $(\mathrm{CV})$ for 6 parallel experiments varied from 0.1 to $0.7 \%$. The separation efficiencies for fructose and glucose in these conditions were within 96.3-101.9\% (Amberlite IRP-69), 97.8-101.3\% (Dowex 50W ×8-200), 96.0-101.5\% (Dowex 50W $\times 8-400$ ) and 98.8-101.6\% (Dowex 50W HCR-W2) with the CV values for all the results within the range of $0.3-4.9 \%$. Unfortunately, it was also established that the $\mathrm{K}$ and $\mathrm{Na}$ ions are exhaustively retained by all the resins at the studied $\mathrm{pH}$ range (3.5-4.5). The retention efficiencies of $\mathrm{K}$ and $\mathrm{Na}$ in these conditions were within 96.9-100.0\% (Amberlite IRP-69), 99.8-100.0\% (Dowex 50W $\times 8-200$ ), 99.9-100.0\% (Dowex 50W $\times 8-$ 200) and 99.5-99.7\% (Dowex 50W HCR-W2). The reproducibility of these results were in the range of 0.1 $0.7 \%$ (as $\mathrm{CV}, \mathrm{n}=6$ ).

In a similar way, the effect of the flow rate (in the range from 2.0 to $20 \mathrm{~mL} \mathrm{~min}^{-1}$ ) with which the working standard solutions were driven through the SPE columns was assessed on the retention efficiencies of $\mathrm{Ca}, \mathrm{K}, \mathrm{Mg}$ and $\mathrm{Na}$ and the separation efficiencies of fructose and glucose. Here, the working standard solutions ( $\mathrm{pH} 4.0$ ) were passed through the SPE columns at the different flow rates and the respective column effluents were collected and analyzed on the content of the elements $(\mathrm{Ca}, \mathrm{K}, \mathrm{Mg}, \mathrm{Na})$ and the monosaccharides (fructose and glucose).

Apparently, it was determined that all the Dowex resins exhaustively retain the $\mathrm{Ca}(\mathrm{II})$ and $\mathrm{Mg}$ (II) ions at the flow rates much higher than $2.0 \mathrm{~mL} \mathrm{~min}^{-1}$, i.e., 4.0, $6.0,8.0,10,14$ and even 18 and $20 \mathrm{~mL} \mathrm{~min}^{-1}$. The average retention efficiencies of $\mathrm{Ca}$ and $\mathrm{Mg}$ calculated for the individual retention efficiencies obtained at the different flow rates corresponded to $99.6 \pm 0.2$ and $100.0 \pm 0.1 \%$ (Dowex 50W $\times 8-200$ ), $99.6 \pm 0.2$ and $99.9 \pm 0.1 \%$ (Dowex 50W $\times 8-400$ ) and $99.5 \pm 0.3$ and $99.6 \pm 0.5 \%$ (Dowex 50W HCR-W2). Unfortunately, it was not possible to use the flow rates higher than $14 \mathrm{~mL} \mathrm{~min}^{-1}$ for the resin 
Amberlite IRP-69. A strong resistance in the flow of the solution was observed in this case, likely due to the small particle size of this resin, i.e., 25-180 mm. Nevertheless, the average retention efficiencies of $\mathrm{Ca}$ and $\mathrm{Mg}$ evaluated for this resin on the basis of the individual retention efficiencies achieved at the flow rate within the range of $2.0-14 \mathrm{~mL} \mathrm{~min}^{-1}$ were $99.7 \pm 0.2$ and $100.0 \pm 0.1 \%$, respectively. In case of all the resins, fructose and glucose were separated from the $\mathrm{Ca}(\mathrm{II})$ and $\mathrm{Mg}(\mathrm{II})$ ions irrespectively of the flow rate used. Accordingly, the sums of the concentrations of both monosaccharides determined in the column effluents were practically the same as in the working standard solutions loaded onto the columns. Unfortunately, in these conditions, the $\mathrm{K}$ and $\mathrm{Na}$ ions were quantitatively retained by the resins as well. The retention efficiencies established for these elements at the different flow rates were within 99.3-100.0\% (Amberlite IRP-69), 99.8-100.0\% (Dowex 50W×8-200), 99.7-100.0\% (Dowex $50 \mathrm{~W} \times 8-400$ ) and $99.6-100.0 \%$ (Dowex 50W HCR-W2) with the reproducibility of these results within $0.1-0.6 \%$ (as $\mathrm{CV}, \mathrm{n}=6$ ).

Considering the cation exchange behavior of the studied resins, Dowex $50 \mathrm{~W} \times 8-400$ with the particle size of 38-74 $\mathrm{mm}$ was selected for further experiments.

\section{Removal of $\mathrm{K}$ with $\mathrm{Na}$ and elution of $\mathrm{Ca}$ and $\mathrm{Mg}$}

Although the analytical response of slightly ionized $\mathrm{Mg}$ in the air-acetylene flame is recognized not to be changed much with the varying content of $\mathrm{K}$ and $\mathrm{Na}$, the response of $\mathrm{Ca}$ is recognized to significantly increase in the presence of the alkali metals, especially when they are at the moderately high levels in the solutions (up to $250 \mathrm{mg} \mathrm{mL}^{-1}$ ). ${ }^{20}$ Therefore, to eliminate the possible non-spectral interferences in the air-acetylene flame used here and originating from the presence of $\mathrm{K}$ and $\mathrm{Na}$ in the analyzed sample solutions, it was decided to find out the conditions of the removal of both alkali metals before the elution of the $\mathrm{Ca}$ (II) and $\mathrm{Mg}$ (II) ions and the measurements of the concentrations of these elements by FAAS. Considering the cation exchange behavior of the monovalent metal ions on the strong cation exchange resins, it was presumed that the diluted solutions of the common mineral acids could elute the $\mathrm{K}$ and $\mathrm{Na}$ ions not removing such divalent metal ions as $\mathrm{Ca}$ (II) and $\mathrm{Mg}$ (II), which are usually retained on this type of the resins much stronger. ${ }^{21}$

To evaluate the suitability of the 0.2 and $0.5 \mathrm{~mol} \mathrm{~L}^{-1}$ $\mathrm{HCl}$ and $\mathrm{HNO}_{3}$ solutions for the removal of the $\mathrm{K}$ and $\mathrm{Na}$ ions from the selected cation exchange resin Dowex $50 \mathrm{~W} \times 8-400$, the working standard solutions $(\mathrm{pH} 4.0)$ were driven at first through the SPE columns at the flow rate of $20 \mathrm{~mL} \mathrm{~min}^{-1}$. Then, the tested solutions in three portions of
$10 \mathrm{~mL}$ each were passed at the flow rate of $2.0 \mathrm{~mL} \mathrm{~min}^{-1}$ through the SPE columns to strip off the $\mathrm{K}$ and $\mathrm{Na}$ ions. The respective $10 \mathrm{~mL}$ portions of the column eluates were collected and the concentrations of $\mathrm{Ca}, \mathrm{K}, \mathrm{Mg}$ and $\mathrm{Na}$ were determined against the simple standard solutions of these elements.

It was found that the quantitative recovery of the $\mathrm{K}$ and $\mathrm{Na}$ ions from the resin beds of Dowex $50 \mathrm{~W} \times 8-400$ was obtained using a $0.5 \mathrm{~mol} \mathrm{~L}^{-1} \mathrm{HNO}_{3}$ solution. With $20 \mathrm{~mL}$ of this solution, already $99.7 \pm 3.7 \%$ of the total $\mathrm{K}$ and $97.3 \pm 3.4 \%$ of the total $\mathrm{Na}$ retained by the resin were recovered while $\mathrm{Ca}$ and $\mathrm{Mg}$ remained in these conditions practically unchanged on the SPE columns (the recoveries of $\mathrm{Ca}$ and $\mathrm{Mg}$ were $1.7 \pm 0.2 \%$ and $0.4 \pm 0.4 \%$, respectively). A less concentrated solution of $\mathrm{HNO}_{3}$ $\left(0.2 \mathrm{~mol} \mathrm{~L}^{-1}\right)$ was established to be useless since its $20 \mathrm{~mL}$ resulted in the recovery of $0.4 \pm 0.1 \%$ of the total $\mathrm{K}_{\text {only }}$ and $75.7 \pm 3.4 \%$ of the total $\mathrm{Na}$. The use of a $0.5 \mathrm{~mol} \mathrm{~L}^{-1}$ $\mathrm{HCl}$ solution was also discarded. Although $20 \mathrm{~mL}$ of this solution led to the quantitative recovery of the total $\mathrm{Na}$ retained $(102.5 \pm 4.4 \%)$, $\mathrm{K}$ was stripped with the efficiency lower than $90 \%$.

In next turn, the effectiveness of 1.0, 2.0, 3.0 and $4.0 \mathrm{~mol} \mathrm{~L}^{-1} \mathrm{HCl}$ solutions was studied in respect to the elution of the $\mathrm{Ca}(\mathrm{II})$ and $\mathrm{Mg}(\mathrm{II})$ ions retained on the resin. For that purpose, the working standard solutions ( $\mathrm{pH} 4.0$ ) were passed through the SPE columns of Dowex $50 \mathrm{~W} \times 8-400$ at the flow rate of $20 \mathrm{~mL} \mathrm{~min}{ }^{-1}$ to separate fructose and glucose and subsequently, the retained $\mathrm{K}$ and $\mathrm{Na}$ ions were removed by passing $20 \mathrm{~mL}$ of a $0.5 \mathrm{~mol} \mathrm{~L}^{-1}$ $\mathrm{HNO}_{3}$ solution. At the end, $5-\mathrm{mL}$ portions of given $\mathrm{HCl}$ solutions were passed through the SPE columns to recover $\mathrm{Ca}$ and $\mathrm{Mg}$; the respective eluates were collected, diluted to $25 \mathrm{~mL}$ with water and subjected to the analysis on the content of $\mathrm{Ca}$ and $\mathrm{Mg}$ by FAAS versus the simple standard solutions. The recovery efficiencies (in \%) of $\mathrm{Ca}, \mathrm{K}, \mathrm{Mg}$ and $\mathrm{Na}$ were calculated relating the concentrations of the elements determined in the respective eluates to their original concentrations in the working standard solutions.

Apparently, it was found that except for a $1.0 \mathrm{~mol} \mathrm{~L}^{-1}$ $\mathrm{HCl}$ solution, the others lead to the quantitative release of $\mathrm{Ca}$ and $\mathrm{Mg}$. The respective recovery efficiencies were $99.8 \pm 2.7 \%(\mathrm{Ca})$ and $99.6 \pm 1.9 \%(\mathrm{Mg})$ in case of a $2.0 \mathrm{~mol} \mathrm{~L}^{-1} \mathrm{HCl}$ solution, $101.3 \pm 2.4 \%(\mathrm{Ca})$ and $98.2 \pm 3.5 \%(\mathrm{Mg})$ for a $3.0 \mathrm{~mol} \mathrm{~L}^{-1} \mathrm{HCl}$ solution and $99.2 \pm 1.8 \%(\mathrm{Ca})$ and $101.2 \pm 3.1 \%(\mathrm{Mg})$ in case of a $4.0 \mathrm{~mol} \mathrm{~L}^{-1} \mathrm{HCl}$ solution.

Considering all these results, it was decided that $20 \mathrm{~mL}$ of a $0.5 \mathrm{~mol} \mathrm{~L}^{-1} \mathrm{HNO}_{3}$ solution and $5 \mathrm{~mL}$ of a $2.0 \mathrm{~mol} \mathrm{~L}^{-1}$ $\mathrm{HCl}$ solution would be applied for the two-step elution in the proposed sample preparation SPE procedure. 


\section{Analytical characteristics and application}

Considering the ion exchange capacity of the Dowex 50W'8-400 resin toward the $\mathrm{Ca}(\mathrm{II})$ and $\mathrm{Mg}(\mathrm{II})$ ions, which was determined to be 66 and $72 \mathrm{mg}$ of $\mathrm{Ca}$ and $\mathrm{Mg}$, respectively, per $\mathrm{g}$ of the resin as received, and the highest possible concentrations of $\mathrm{K}$ and $\mathrm{Na}$ in honey samples, reaching even 6.5 and $1.2 \mathrm{mg} \mathrm{g}^{-1}$, respectively, it was decided that $5.0 \%(\mathrm{~m} / \mathrm{v})$ sample solutions of the analyzed honeys would be prepared and treated with the SPE procedure proposed.

The accuracy of this procedure was evaluated by the recovery of the known amounts of the $\mathrm{Ca}$ (II) and $\mathrm{Mg}$ (II) ions $\left(0.5,1.5\right.$ and $3.5 \mathrm{mg} \mathrm{mL}^{-1}$ in case of $\mathrm{Ca}$ and $0.3,0.6$ and $1.2 \mathrm{mg} \mathrm{L}^{-1}$ in case of $\mathrm{Mg}$ ) added to the $5.0 \%(\mathrm{~m} / \mathrm{v})$ solutions of goldenrod, heather and rape honeys to double the original concentrations of these elements. The recoveries achieved were in the range of 97.1-102.2\% for $\mathrm{Ca}$ and 98.6-101.7\% for $\mathrm{Mg}$. The precision (as $\mathrm{CV}$ ) obtained was within
2.0-5.1\% for $\mathrm{Ca}$ and $0.7-3.2 \%$ for $\mathrm{Mg}$. The intermediate precision within three consecutive days was better than 6.8 and $5.3 \%$, respectively in case of $\mathrm{Ca}$ and $\mathrm{Mg}$. The limits of detection (LODs) of $\mathrm{Ca}$ and $\mathrm{Mg}$ achieved for FAAS after the execution of this procedure were expressed as the concentrations of these elements that correspond to the absorbance signals of 3 standard deviations of the means for the repeated $(n=5)$ measurements of the respective procedural blanks. These LODs were found to be 1.2 and $0.2 \mathrm{ng} \mathrm{mL}{ }^{-1}$, respectively for $\mathrm{Ca}$ and $\mathrm{Mg}$. In the relation to the solid matrix it was 24 and $4.4 \mathrm{ng} \mathrm{g}^{-1}$, respectively. The limits of quantification (LOQs) for $\mathrm{Ca}$ and $\mathrm{Mg}(10 \sigma$ criterion) were 4.1 and $0.8 \mathrm{ng} \mathrm{mL}^{-1}$, correspondingly. The linearity ranges were $200 \mu \mathrm{g} \mathrm{g}^{-1}(\mathrm{Ca})$ and $40 \mu \mathrm{g} \mathrm{g} \mathrm{g}^{-1}(\mathrm{Mg})$.

Next, the proposed sample preparation procedure based on the SPE separation and the two-step elution (procedure D) was used to determine the concentrations of $\mathrm{Ca}$ and $\mathrm{Mg}$ in six mono- and multi-flower honeys. Three other sample preparation procedures, namely the decomposition in

Table 2. The concentrations of Ca and Mg determined by FAAS in the samples of bee honeys prepared using the different sample treatment

\begin{tabular}{|c|c|c|c|c|}
\hline \multirow{2}{*}{ Honeys } & \multicolumn{2}{|c|}{ Concentration / $\left(\mu \mathrm{g} \mathrm{g}^{-1}\right)$} & \multicolumn{2}{|c|}{$t_{\text {calculated }}{ }^{\mathrm{a}}$} \\
\hline & $\mathrm{Ca}$ & $\mathrm{Mg}$ & $\mathrm{Ca}$ & $\mathrm{Mg}$ \\
\hline \multicolumn{5}{|c|}{ Procedure $\mathrm{A}$ (the open vessel digestion in mixture of $\mathrm{HNO}_{3}$ and $\mathrm{H}_{2} \mathrm{O}_{2}$ ) } \\
\hline Acacia & $12.96 \pm 0.55(4.2)$ & $6.49 \pm 0.17(2.6)$ & +0.121 & +3.687 \\
\hline Goldenrod & $65.24 \pm 4.06(6.2)$ & $18.68 \pm 0.24(1.3)$ & -0.130 & +1.586 \\
\hline Heather & $74.20 \pm 3.41(4.6)$ & $19.05 \pm 0.20(1.0)$ & +0.560 & +2.044 \\
\hline Lime & $62.39 \pm 2.10(3.4)$ & $17.89 \pm 0.18(1.0)$ & +0.592 & -3.795 \\
\hline Multi-flower & $31.19 \pm 1.08(3.5)$ & $10.37 \pm 0.29(2.8)$ & +1.443 & +3.223 \\
\hline$\underline{\text { Rape }}$ & $38.58 \pm 2.85(7.4)$ & $14.29 \pm 0.25(1.7)$ & -0.152 & -0.479 \\
\hline \multicolumn{5}{|c|}{ Procedure $\mathrm{B}$ (the open vessel digestion in $\mathrm{H}_{2} \mathrm{O}_{2}$ ) } \\
\hline Acacia & $12.29 \pm 0.25(2.0)$ & $6.33 \pm 0.54(8.5)$ & +1.791 & +1.777 \\
\hline Goldenrod & $65.95 \pm 1.07(1.6)$ & $18.11 \pm 1.19(6.6)$ & -1.069 & +1.186 \\
\hline Heather & $76.60 \pm 3.45(4.5)$ & $20.94 \pm 1.59(7.6)$ & -0.370 & -1.124 \\
\hline Lime & $63.02 \pm 2.95(4.7)$ & $17.12 \pm 1.09(6.4)$ & +0.118 & +0.202 \\
\hline Multi-flower & $32.27 \pm 2.07(6.4)$ & $10.75 \pm 1.32(12.3)$ & +0.208 & +0.524 \\
\hline$\underline{\text { Rape }}$ & $39.02 \pm 1.12(2.9)$ & $13.47 \pm 1.30(9.7)$ & -0.866 & +0.939 \\
\hline \multicolumn{5}{|c|}{ Procedure $\mathrm{C}$ (the dissolution in water) } \\
\hline Acacia & $12.53 \pm 0.63(5.0)$ & $6.97 \pm 0.07(1.0)$ & +0.930 & -1.303 \\
\hline Goldenrod & $64.54 \pm 1.47(2.3)$ & $18.82 \pm 0.12(0.6)$ & +0.329 & +1.077 \\
\hline Heather & $74.89 \pm 2.51(3.4)$ & $20.30 \pm 0.27(1.3)$ & +0.340 & -1.188 \\
\hline Lime & $62.57 \pm 1.77(2.8)$ & $17.17 \pm 0.16(0.9)$ & +0.524 & +0.495 \\
\hline Multi-flower & $32.74 \pm 0.26(0.8)$ & $10.88 \pm 0.06(0.6)$ & -0.246 & +1.536 \\
\hline Rape & $39.21 \pm 0.67(1.7)$ & $14.49 \pm 0.18$ & -1.435 & -1.601 \\
\hline
\end{tabular}

Procedure D (the dissolution in water followed by the SPE and the two-step elution)

\begin{tabular}{lcc} 
Acacia & $13.02 \pm 0.66(5.1)$ & $6.89 \pm 0.08(1.2)$ \\
Goldenrod & $64.92 \pm 1.28(2.0)$ & $18.93 \pm 0.13(0.7)$ \\
Heather & $75.64 \pm 2.88(3.8)$ & $19.83 \pm 0.63(3.2)$ \\
Lime & $63.24 \pm 1.33(2.1)$ & $17.25 \pm 0.23(1.3)$ \\
Multi-flower & $32.56 \pm 1.24(3.8)$ & $11.16 \pm 0.31(2.8)$ \\
Rape & $38.32 \pm 0.84(2.2)$ & $14.19 \pm 0.27(1.9)$ \\
\hline
\end{tabular}

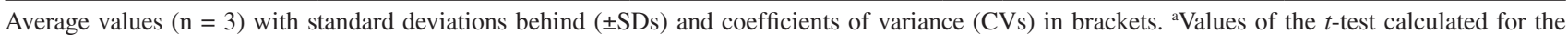
comparison of the average results obtained for the procedures $\mathrm{A}, \mathrm{B}$ and $\mathrm{C}$ with those obtained for the procedure $\mathrm{D}\left(t_{\text {critical }}=4.303\right.$, $\left.\mathrm{p}=0.05\right)$. 
$\mathrm{HNO}_{3}$ and $\mathrm{H}_{2} \mathrm{O}_{2}$ (procedure $\mathrm{A}$ ), the decomposition in $\mathrm{H}_{2} \mathrm{O}_{2}$ (procedure $\mathrm{B}$ ) and the dissolution in water (procedure $\mathrm{C}$ ), were used and the resulting $5.0 \%(\mathrm{~m} / \mathrm{v})$ honey solutions were analyzed as well. The results obtained with the aid of these procedures $(\mathrm{A}, \mathrm{B}, \mathrm{C})$ were compared to those obtained with the proposed procedure D using the $t$-test at the $95 \%$ level of the significance. ${ }^{22}$

As can be seen from Table 2, the proposed sample preparation procedure combining the SPE separation of the monosaccharides and the anionic minerals (especially the phosphates), followed by the removal of $\mathrm{K}$ with $\mathrm{Na}$ and the elution of $\mathrm{Ca}$ and $\mathrm{Mg}$, offers the precision (as $\mathrm{CV}$ ) within 2.0-5.1\% in case of $\mathrm{Ca}$ and $0.7-3.2 \%$ in case of $\mathrm{Mg}$. The re-usability of the resin was high since the reproducibility of the results obtained using one SPE column for 25 analyses was $6.5 \%$ (as CV). The time investment required for this procedure was $30 \mathrm{~min}$. The analyzed solutions resulted from the dilution of the eluents did not require to be admixed with the solutions of the aiding substances.

The differences between the results achieved with the proposed SPE sample preparation procedure (procedure D) and the other sample preparation procedures are statistically insignificant. The values of the calculated parameter $t$ are lower than the critical value of 4.303. Nevertheless, as compared to the other procedures, it seems that the precision (as CV) achieved for the repeated analysis of the samples $(n=3)$ for the wet oxidative digestion procedures is lower (see the results in Table 2 for $\mathrm{Ca}$ in the procedure $\mathrm{A}$ and $\mathrm{Mg}$ in the procedure $\mathrm{B}$ ).

Besides, the time investment required to complete the decomposition of the samples and the dilution of their digests with the releasing buffers was high, i.e., 240 and $180 \mathrm{~min}$, respectively for the procedure A and B. The precision (as CV) assessed for the direct analysis of the solutions resulted from the dissolution of the honey samples is comparable to this achieved with the SPE procedure in case of $\mathrm{Ca}(0.8-5.0 \%)$ and a slightly better for $\mathrm{Mg}(0.6-1.3 \%)$. The time investment required for the preparation of the sample solutions and their dilution with the solutions of the releasing buffers before the measurements of $\mathrm{Ca}$ and $\mathrm{Mg}$ by FAAS was also comparable to this assessed for the SPE procedure, i.e., about $30 \mathrm{~min}$. However, it should be noted that since the overall content of the organic substances, especially fructose and glucose, in the analyzed samples is not known, as a part of the quality assurance and control, the individual samples of honey have to be differently diluted, e.g., 100, 50 and 20 times, what corresponds to the preparation of their 1.0, 2.0 and $5.0 \%$ $(\mathrm{m} / \mathrm{v})$ sample solutions, and analyzed. This is aimed at finding out such a suitable content of honey that dissolved in water would not result in the physical interferences in the transport and the aspiration rate of the prepared solutions. In consequence, more samples have to be analyzed and the analysis time is much longer than stated $30 \mathrm{~min}$.

\section{Conclusions}

This paper reports on the development of the sample preparation procedure that employs the solid phase extraction and the two-step extraction for the determination of the concentrations of $\mathrm{Ca}$ and $\mathrm{Mg}$ in honey by FAAS. The latter elements are separated from fructose, glucose and the anionic minerals in addition to $\mathrm{K}$ and $\mathrm{Na}$ what makes that the prolonged decomposition of the samples or the usage of the additional aiding substances can be freely omitted before the measurements. The procedure was demonstrated to be fast, straightforward and interference free. In this way, it could be a useful alternative to the time-consuming and laborious wet digestion procedures.

\section{Acknowledgments}

This project is implemented with the co-financing of the European Union within the European Social Fund. The National Science Center is acknowledged for receiving the funding for the research project carried out by a predoctoral researcher starting a scientific career.

\section{References}

1. Baroni, M. V.; Arrua, C.; Nores, M. L.; Faye, P.; Diaz, M. P.; Chiabrando, G. A.; Wunderlin, D. A.; Food Chem. 2009, 114, 727.

2. Lachman, J.; Kolihova, D.; Miholova, D.; Kosata, J.; Titera, D.; Kult, K.; Food Chem. 2007, 101, 973.

3. Hernandez, O. M.; Fraga, J. M. G.; Jimenez, A. I.; Jimenez, F.; Arias, J. J.; Food Chem. 2005, 93, 449.

4. Lopez Garcia, I.; Vinas, P.; Blanco, C.; Hernandez Cordoba, M.; Talanta 1999, 49, 597.

5. Uren, A.; Serifoglu, A.; Sarikahya, Y.; Food Chem. 1998, 61, 185.

6. Pohl, P.; Sergiel, I.; Stecka, H.; Crit. Rev. Anal. Chem. 2009 , $39,276$.

7. Juszczak, L.; Socha, R.; Roznowski, J.; Fortuna, T.; Nalepka, K.; Food Chem. 2009, 113, 538.

8. Silva, L. R.; Videira, R.; Monteiro, A. P.; Valentao, P.; Andrade, P. B.; Talanta 2009, 93, 73.

9. dos Santos, J. S.; dos Santos, N. S.; dos Santos, M. L. P, dos Santos, S. N.; Lacerda, J. J. J.; J. Braz. Chem. Soc. 2008, 19, 502.

10. Silici, S.; Uluozlu, O. D.; Tuzen, M.; Soylak, M.; J. Hazard. Mater. 2008, 156, 612. 
11. Stankovska, E.; Stafilov, T.; Sajn, R.; Environ. Monit. Assess. 2008, 142, 117.

12. Tuzen, M.; Fresenius Environ. Bull. 2002, 11, 366.

13. Tuzen, M.; Duran, M.; Adv. Food. Sci. 2002, 24, 125.

14. Sergiel, I.; Pohl, P.; J. Agric. Food Chem. 2010, 58, 7497.

15. Vit, P.; Rodriguez-Malaver, A.; Rondon, C.; Gonzalez, I.; di Bernardo, M. L.; Garcia, M. Y.; Arch. Latinoam. Nutr. 2010, $60,405$.

16. Pohl, P.; Prusisz, B.; Talanta 2006, 69, 1227.

17. Madejczyk, M.; Baralkiewicz, D.; Anal. Chim. Acta 2008, 617, 11.

18. Chudzinska, M.; Baralkiewicz, D.; Food Chem. Toxicol. 2010, $48,284$.
19. Fournier, E. In Handbook of Food Analytical Chemistry; Wrolstad, R. E.; Acree, T. E.; Decker, E. A.; Penner, M. H.; Reid, D. S.; Schwartz, S. J.; Shoemaker, C. F.; Smith, D.; Sporns P., eds.; John Wiley \& Sons: New York, 2005, pp. 651-660.

20. Pinta, M.; Atomic Absorption Spectrometry, Halstead Press: New York, 1975.

21. Zagorodni, A. A.; Ion Exchange. Materials, Properties and Applications, Elsevier: Amsterdam, 2007.

22. Miller, J. N.; Miller, J. C.; Statistics and Chemometrics for Analytical Chemistry, Pearson Education: Harlow, UK, 2005.

Submitted: December 16, 2011

Published online: March 6, 2012 